\title{
Variasi Karakter Anatomis Talus Padina australis Hauck 1887 (Dictyotales, Phaeophycota) di Pantai Karang Tengah Kabupaten Cilacap
}

\author{
Siti Samiyarsih, Moch Iqbal Sufyan Ats'tsaury, Achmad llalqisny Insan, Nur Fitrianto* \\ Departemen Botani, Fakultas Biologi, Universitas Jenderal Soedirman \\ Jalan Dr. Suparno No. 63 Purwokerto, Banyumas, Jawa Tengah 53122 Indonesia \\ ${ }^{*}$ Corresponding author, e-mail : nurfitrianto17@gmail.com
}

\begin{abstract}
ABSTRAK: Karakter anatomi dapat digunakan untuk menentukan produktivitas kandungan alginat rumput laut $P$. australis Hauck. Penelitian ini bertujuan mengetahui variasi karakter anatomis talus Padina australis Hauck. Pengambilan sampel dengan purposive random sampling di pantai Karang Tengah, Kabupaten Cilacap. Persiapan mikroskopis dengan metode parafin dengan safranin $1 \%$ dalam alkohol $70 \%$. Parameter yang diamati meliputi ketebalan epidermis, ukuran sel medula, ketebalan talus, dan ukuran tetra sporangia. Pengamatan struktur anatomi secara deskriptif dengan membandingkan karakter anatomi P. australis Hauck pada garis konsentris. Data karakter anatomi dianalisis dengan Uji-t dengan tingkat kepercayaan 95\%. Hasil penelitian menunjukkan bahwa variasi karakter anatomi talus dengan garis konsentris 5 memiliki ketebalan epidermis adaxial dan abaxial masing-masing adalah $20,05 \mu \mathrm{m}$ dan $12,55 \mu \mathrm{m}$, sedangkan pada garis konsentris 7 memiliki ketebalan $28,33 \mu \mathrm{m}$ dan $18 \mu \mathrm{m}$. Ketebalan talus dengan garis konsentris 5 dan 7 masingmasing adalah 99,44 $\mu \mathrm{m}, 114,77 \mu \mathrm{m}$. Diameter meduler dengan garis konsentris 5 dan 7 masingmasing adalah $37,88 \mu \mathrm{m}, 45,5 \mu \mathrm{m}$. Diameter rata-rata tetra sporangia masing-masing dengan garis konsentris 5 dan 7 yaitu 25,66 $\mu \mathrm{m}, 35,66 \mu \mathrm{m}$. Talus $P$. australis Hauck berdasarkan garis konsentris 5 dan 7 memiliki perbedaan ukuran pada ketebalan epidermis adaxial, ketebalan epidermis abaxial, ketebalan talus, diameter meduler, dan diameter tetra sporangia. Implikasi penelitian ini sebagai database pada data dasar karakter anatomi P. australis yang dikaitkan denggan produktsi alginat dan data dasar taksonomi.
\end{abstract}

Kata kunci: anatomi; Padina australis; talus

\section{Anatomical Variations of Padina australis Hauck 1887 (Dictyotales, Phaeophycota) Thallus in Karang Tengah Beach, Cilacap Regency}

ABSTRACT: Anatomical character data can be used to determine the productivity of $P$. australis Hauck's seaweed alginate content. Each thallus has a thallus size and the number of varied concentric lines. The aim of the research is to determine the anatomical characteristics of the Padina australis Hauck thallus. Seaweed sampling by purposive random sampling technique in Karang Tengah beach, Cilacap regency. Preparation of microscopic by paraffin method with safranin $1 \%$ in $70 \%$ alcohol. Parameters observed included thickness of the epidermis, size of a medullary cell, the thickness of thallus, and the size of tetra sporangia. The anatomical character data was analyzed by $t$-Test with a 95\% confidence level. The result of the research showed that the anatomical character of the thallus with concentric line 5 had a thickness of adaxial and abaxial epidermis respectively is $20.05 \mu \mathrm{m}$ and $12.55 \mu \mathrm{m}$, whereas in concentric line 7 had a thickness of $28.33 \mu \mathrm{m}$ and $18 \mu \mathrm{m}$. The thickness of the thallus with concentric lines 5 and 7 respectively is $99.44 \mu \mathrm{m}, 114.77 \mu \mathrm{m}$. Medullary diameter with concentric lines 5 and 7 respectively is $37,88 \mu \mathrm{m}, 45,5 \mu \mathrm{m}$. The average diameter of tetra sporangia with concentric lines 5 and 7 respectively that is $25,66 \mu \mathrm{m}, 35,66 \mu \mathrm{m}$. Thallus of $P$. australis Hauck based on concentric lines 5 and 7 has differences of sizes on the adaxial epidermal thickness, thickness of the abaxial epidermis, the thickness of the thallus, medullary diameter, and diameter of tetra sporangia. The implications anatomical characters associated with alginate productivity and taxonomic baseline data.

Keywords: anatomy, Padina australis, thallus 


\section{PENDAHULUAN}

Rumput laut coklat merupakan salah satu sumber daya alam laut yang keberadaannya sangat melimpah dan tumbuh secara alami di perairan pantai Indonesia, namun potensi ini belum dimanfaatkan secara optimal. Pada umumnya rumput laut mengandung tiga jenis hidrokoloid, yaitu agar-agar, alginat dan karaginan. Alginat merupakan komponen utama penyusun dinding sel rumput laut coklat yang tersusun atas asam alginat, mannuronat dan galakturonat. Alginat merupakan bahan baku yang banyak dimanfaatkan oleh beberapa industri sebagai pengatur keseimbangan, pengemulsi dan pembentuk lapisan tipis tahan minyak (Gerasimenko et al., 2010).

Padina australis Hauck termasuk salah satu rumput laut coklat yang memiliki potensi sebagai sumber alginat, tumbuh di sepanjang perairan Kabupaten Cilacap. Rumput laut tersebut hidup pada beberapa karakteristik lingkungan perairan yang berbeda diantaranya di daerah intertidal di pantai berbatu dan pada beberapa perairan lainnya yang memiliki substrat berpasir dan kondisi lingkungan yang berbeda. Menurut Mushollaeni \& Rusdiana (2011), berdasarkan karakteristik kecerahan dan kandungan abu natrium alginat yang diekstrak, bahwa $P$. australis Hauck memiliki warna alginat yang lebih cerah dan kandungan abu yang lebih tinggi daripada jenis Sargassum dan Turbinaria.

Pertumbuhan dan distribusi rumput laut dipengaruhi oleh sifat fisik, kimia dan dinamika air laut dan substrat habitatnya. Rumput laut mengambil nutrisi dari lingkungan sekitar melalui difusi melalui dinding talus (Kadi, 2005). Studi perbandingan berbagai spesies Padina seringkali membingungkan dala terminologi deskriptif pada karakter morfologi. Karakter anatomi mendukung karakter morfologi yang dapat digunakan sebagai acuan identifikasi dan membandingkan antar spesies pada genus Padina (Abbas \& Shameel,2013).

Perubahan karakter anatomi merupakan salah satu respon terjadinya gangguan metabolisme tubuh dan kemungkinan terjadinya kerusakan akibat cekaman lingkungan yang kurang baik. Kondisi perairan yang tercemar berkonsentrasi tinggi dan terjadi secara terus menerus akan berakibat pada perubahan struktur anatomi dan kematian rumput laut yang tergantung pada tingkat polutan pada lingkungan tercemar (polluted water) (Yulianto et al., 2006). Secara anatomi penyusun talus terdiri dari tiga jenis sel dari luar ke dalam yaitu, sel epidermis, korteks dan medula. Epidermis terdiri dari satu atau dua lapis sel berukuran terkecil. Ukuran sel korteks lebih besar daripada sel epidermis dan sel korteks ini tersusun oleh dua lapis sel. Semakin ke dalam, bentuk sel semakin besar yang dikenal sebagai sel medula yang terletak di tengah atau paling dalam (Pramesti et al., 2016).

Bagian yang menyerupai kipas terdapat garis-garis horisontal yang disebut garis konsentris. Garis konsentris pada $P$. australis Hauck mudah dilhat secara kasat mata tanpa menggunakan mikroskop. Garis konsentris atau concentric hair lines berkembang dengan baik pada permukaan bawah pada talus. Selain itu, didalam garis konsentris terdapat organ reproduksi yang disebut dengan tetrasporangia. Garis konsentris diindikasikan sebagai pertumbuhan dari $P$. australis Hauck, semakin banyak garis konsentris maka umur dari rumput laut $P$. australis Hauck semakin bertambah. Setiap talus $P$. australis Hauck memiliki ukuran talus dan banyaknya jumlah garis konsentris yang bervariasi.

Variasi karakter anatomi rumput laut khususnya $P$. australis Hauck sejauh ini belum pernah dilakukan. Kebaruan penelitian ini adalah mengetahui karakteristik struktur anatomi talus bentuk kipas $P$. australis Hauck berdasarkan garis konsentris serta mengetahui perbedaan karakter anatomi berdasarkan banyaknya garis konsentris dan bagian talus. Hasil penelitian ini diharapkan dapat dijadikan dasar informasi ilmiah mengenai variasi struktur anatomi $P$. australis dan selanjutnya dapat dihubungkan dengan kemampuan produktivitas alginat.

\section{MATERI DAN METODE}

Pengambilan sampel rumput laut $P$. australis Hauck dilaksanakan di Pantai Karang Tengah Kabupaten Cilacap, Provinsi Jawa Tengah. Kabupaten Cilacap terletak diantara 108 4'30" - 109 30'30" garis Bujur Timur dan $7^{\circ} 30^{\prime} 20^{\prime \prime}$ - $7^{\circ} 45^{\prime} 20^{\prime \prime}$ garis Lintang Selatan. Pengamatan struktur anatomi $P$. australis Hauck dilaksanakan di Laboratorium Struktur dan Perkembangan Tumbuhan, Fakultas Biologi Universitas Jenderal Soedirman.

Metode yang digunakan adalah metode survei dengan teknik pengambilan sampel secara acak 
terpilih (purposive random sampling). Penentuan pengambilan sampel penelitian didasarkan pada survei pendahuluan yaitu survei untuk mengamati keberadaan $P$. australis Hauck di Perairan Cilacap. Berdasarkan hasil survei tersebut, ditetapkan Pantai Karang Tengah sebagai lokasi pengambilan sampel yang merupakan daerah tempat tumbuhnya P.australis Hauck. Pengambilan sampel rumput laut $P$. australis Hauck berdasarkan banyaknya garis konsentris yaitu sampel yang terdapat 5 garis konsentris dan 7 garis konsentris. Sebanyak 9 sampel dari masing-masing banyaknya garis konsentris yaitu terdiri 3 sampel berdasarkan bagian talus (pangkal, tengah dan ujung) dengan masing-masing 3 kali ulangan.

Pembuatan preparat anatomi talus dengan metode paraffin (Sass, 1958 dan modifikasi Samiyarsih et al., 2020) adalah sebagai berikut: Talus dipotong $\pm 1 \mathrm{~cm}$. Fiksasi: Potongan talus tersebut kemudian dimasukkan ke dalam botol flakon yang berisi larutan fiksatif FAA selama 24 jam. Komposisi larutan fiksatif FAA adalah formalin $5 \mathrm{ml}$, asam asetat glasial $5 \mathrm{ml}$ dan alkohol $70 \% 90 \mathrm{ml}$. Dehidrasi: Setelah 24 jam larutan FAA dibuang lalu diganti alkohol dengan konsentrasi secara bertingkat, yaitu 70\%, 80\%, 96\% dan etanol absolut I \& II masing-masing selama 30 menit. Dealkoholisasi (penjernihan): Setelah dehidrasi dilakukan proses dealkoholisasi (penjernihan) yaitu sampel dipindahkan ke dalam larutan etanol-xilol berturut-turut dengan perbandingan etanol dan xilol 3:1, 1:1, 1:3, xilol I, xilol II masing-masing selama 30 menit. Infiltrasi parafin: Potongan sampel dimasukkan ke dalam campuran xilol:parafin 1:9 selama 24 jam di dalam oven dengan temperatur $60^{\circ} \mathrm{C}$. Setelah 24 jam, campuran xilol:parafin 1:9 diganti dengan parafin murni selama 2 jam di dalam oven dengan temperatur $60^{\circ} \mathrm{C}$. Pembuatan Blok: Selanjutnya sampel ditanam dalam kotak karton yang berisi parafin cair, dan diatur posisisnya sehingga tepat berada ditengah dan terselubungi oleh parafin dan dibiarkan membeku. Sectioning: Parafin dilepaskan dari kotak karton, diiris dengan hatihati, lalu ditempel pada kayu (holder) menurut arah sayatan, dilakukan dengan mencairkan sebagian blok parafin dengan skalpel yang telah dipanasi kemudian diletakkan pada kayu (holder). Blok parafin yang berisi organ talus $P$. australis diiris menggunakan mikrotom putar (rotary microtom) dengan tebal irisan $\pm 10 \mu \mathrm{m}$. Penempelan (Affixing) Pita-pita hasil irisan kemudian dilakukan perekatan dengan cara pita parafin diletakkan di atas object glass yang sudah diolesi dengan albumin:gliserin (1:1) dan akuades. Object glass tersebut kemudian diletakkan diatas hot plate sampai pita parafin merenggang.

Pewarnaan: setelah pita parafin merenggang selanjutnya dilakukan deparafinisasi dengan cara object glass yang berisi pita parafin direndam dalam staining jar secara bertingkat dengan larutan xilol I, xilol II, xilol:etanol (3:1), xilol:etanol (1:1), xilol:etanol (1:3), etanol absolut, alkohol 96\%, alkohol 80\%, alkohol $70 \%$ masing-masing selama 30 menit. Setelah itu object glass dimasukkan ke dalam zat warna safranin $1 \%$ dalam alkohol $70 \%$ selama 1-2 jam. Dehidrasi dilakukan secara bertingkat dengan alkohol $70 \%$, alkohol $80 \%$, alkohol $96 \%$, dan etanol absolut masing-masing selama 30 menit. Dealkoholisasi secara bertingkat dengan etanol:xilol (3:1), etanol:xilol (1:1), etanol:xilol (1:3), xilol I, xilol II masingmasing selama 30 menit. Penutupan (Mounting): Irisan talus pada object glass ditetesi dengan entelan dan ditutup dengan cover glass, diberi label dan dikeringkan di atas termostat pada suhu $450 \mathrm{C}$ sampai kering.

Pengukuran tebal epidermis dan talus dilakukan dengan meletakkan preparat pada meja preparat mikroskop. Kemudian dicari fokus bayangan preparat. Pengukuran tebal epidermis dan talus diukur dengan menggunakan mikrometer okuler yang diletakkan pada tabung lensa okuler pada mikroskop perbesaran 400x per $1 \mathrm{~mm}^{2}$ luas talus. Pengukuran masing-masing parameter dilakukan dari arah bagian luar ke bagian dalam. Pengukuran diameter tetrasporangia dan sel medulla dilakukan dengan meletakkan preparat pada meja preparat mikroskop. Kemudian dicari fokus bayangan preparat. Pengukuran diameter tetrasporangia dan sel medula diukur dengan menggunakan mikrometer okuler yang diletakkan pada tabung lensa okuler pada mikroskop perbesaran 400x. Pengukuran masing-masing parameter dilakukan dari arah bagian luar ke bagian dalam Pengukuran dilakukan pada talus bagian ujung, tengah dan pangkal garis konsentris P. australis Hauck dengan masing-masing 3 kali ulangan.

Data yang diperoleh dianalisis secara deskrptif untuk menginterpretasi struktur anatomi talus rumput laut $P$. australis Hauck berdasarkan garis konsentris serta perbedaan karakter anatomi $P$. australis Hauck berdasarkan pada banyaknya garis konsentris dan bagian talus. Data pengukuran karakteristik anatomi $P$. australis Hauck dianalisis Uji t (T-Test) dengan tingkat kepercayaan 95\%. 


\section{HASIL DAN PEMBAHASAN}

Berdasarkan hasil penelitian didapatkan bahwa struktur anatomi talus Padina australis Hauck tersusun atas epidermis, korteks, medula dan tetrasporangia. Jaringan epidermis tersusun atas satu lapisan sel yang berbentuk persegi panjang dan tersusun rapat tanpa ruang antar sel. Sel korteks tersusun atas selapis sel dan berukuran lebih besar dari epidermis. Semakin kedalam ukuran sel semakin besar, memiliki ruang antar sel yang luas sehingga tidak terlalu padat yang disebut sel medula. Tetrasporangia yang merupakan organ reproduksi dari $P$. australis Hauck berbentuk ovate (bulat telur) dengan bagian ujung rounded (membulat). Struktur anatomi talus $P$. australis Hauck berdasarkan garis konsentris 5 yang diamati memiliki struktur anatomi terdiri dari epidermis atas dan bawah, korteks, medula serta tetrasporangia. Hasil pengamatan struktur anatomi dapat dilihat pada Gambar 1.

Struktur anatomi talus $P$. australis Hauck berdasarkan garis konsentris 7 yang diamati memiliki struktur anatomi yang serupa dengan garis konsentris 5. Adapun struktur anatomi talus $P$. australis Hauck berdasarkan garis konsentris 7 tersusun oleh epidermis atas dan bawah, korteks, medula serta tetrasporangia. Hasil pengamatan struktur anatomi dapat dilihat pada Gambar 2.

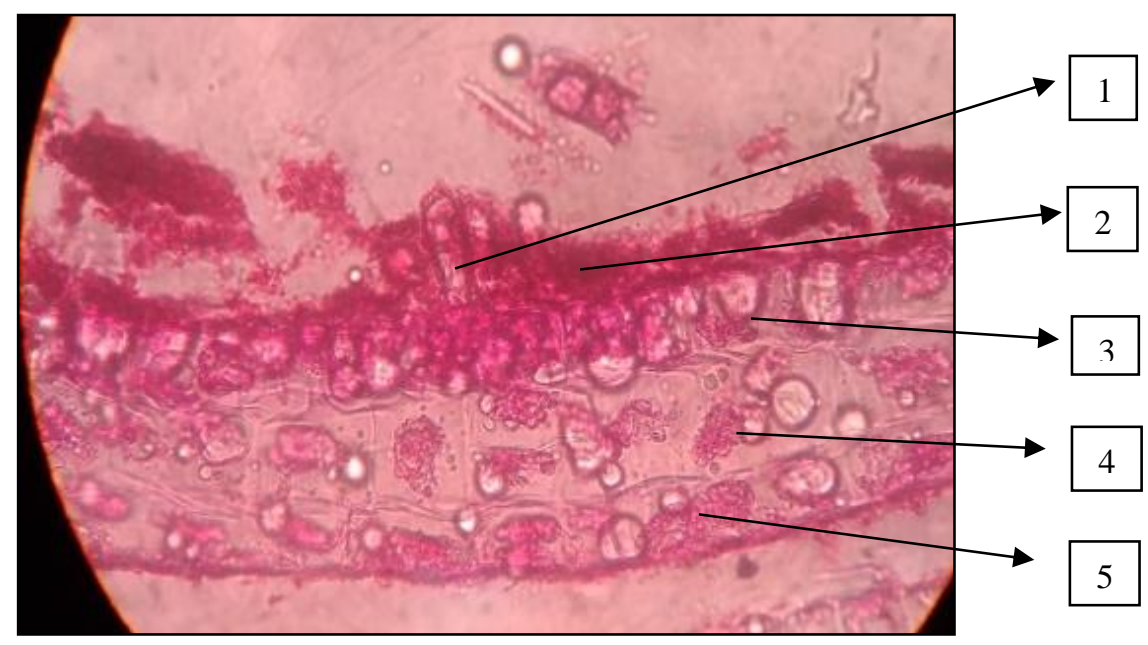

Gambar 1. Struktur Anatomi $P$. australis Hauck dengan Garis Konsentris 5. Tetrasporangia (1); Epidermis atas (2); Korteks (3); Medula (4); Epidermis Bawah (5). Perbesaran 400x.

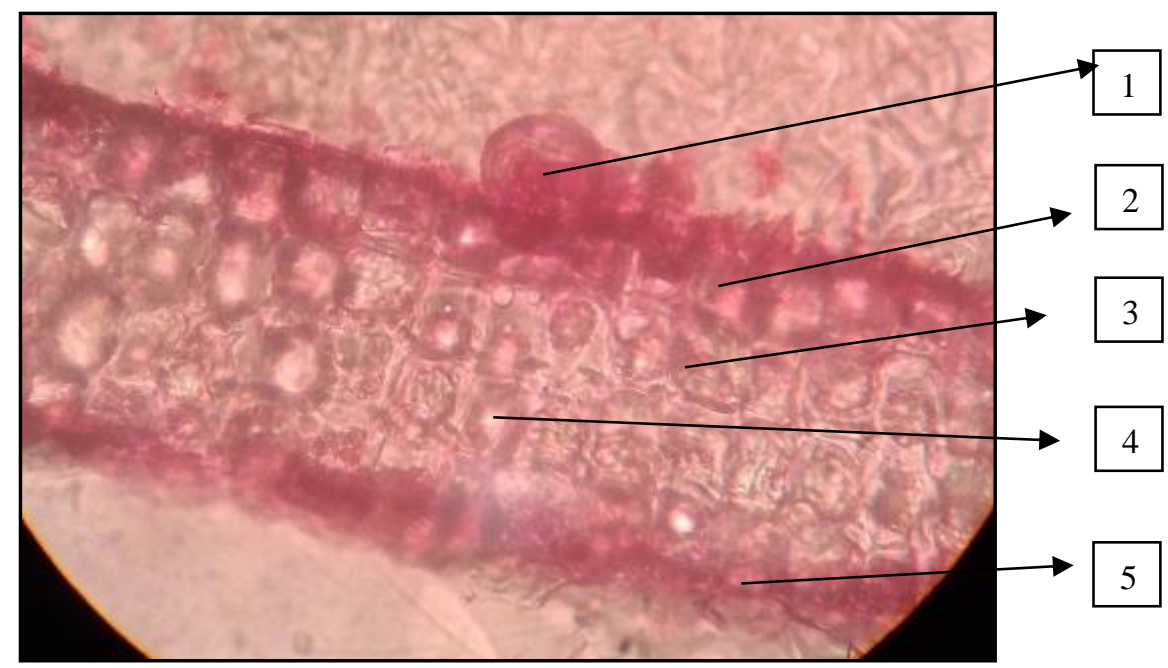

Gambar 2. Struktur Anatomi $P$. australis Hauck dengan Garis Konsentris 7. Tetrasporangia (1); Epidermis atas (2); Korteks (3); Medula (4); Epidermis Bawah (5). Perbesaran 400x. 
Berdasarkan pengamatan, talus terdiri dari lapisan perifer atas dan bawah. Sebanyak 2-3 lapisan kortikal; lapisan periferal terdiri dari sel-sel kecil, kubik, berdinding tipis dengan phaeoplasts padat, panjang 24,3-38,2 $\mu \mathrm{m}$ dan lebar 21,5-37,0 $\mu \mathrm{m}$; sel kortikal, kubik dan persegi panjang, berdinding tipis, tidak terdapat ruang antar sel, dengan panjang 31,0-36,5 $\mu \mathrm{m}$ dan lebar 21,5-24,0 um. Sesuai dengan pernyataan Pramesti et al (2016)., bahwa secara histologi struktur anatomi talus $P$. australis Hauck dapat dibedakan menjadi tiga jaringan dari luar ke dalam yaitu sel epidermis, korteks dan medula. Menurut Qasim et al (2007)., lapisan epidermis umumnya mempunyai satu lapis sel yang berfungsi melindungi jaringan dari lingkungan luar. Sel korteks tersusun atas satu lapisan atau lebih yang berukuran lebih besar dari epidermis, dan sel medula hanya memiliki selapis sel dan ukurannya paling besar. Menurut Riosmena-Rodriguez et al (2009)., tetrasporangia $P$. australis Hauck berasal dari sel korteks dan tersusun dari kumpulan spora yang berbentuk bulat telur (ovate).

Hasil pengukuran terhadap karakter anatomi talus bentuk kipas $P$. australis Hauck berdasarkan garis konsentris 5 dan 7 disajikan pada Gambar 3. Hasil pengukuran rataan tebal epidermis atas pada bagian atau posisi talus berdasarkan garis konsentris 5 dan 7 diperoleh hasil bahwa pada bagian talus ujung dengan garis konsentris 7 memiliki tebal epidermis atas tertinggi yaitu $28,83 \mu \mathrm{m}$ (Tabel 1.). Bagian talus tengah dengan garis konsentris 5 memiliki tebal epidermis atas terendah 16,83 $\mu \mathrm{m}$ (Gambar 3.). Hasil analisis Uji t menunjukkan bahwa terdapat perbedaan tebal epidermis atas antara garis konsentris 5 dan 7, dapat dilihat pada Tabel 1. Pengukuran rataan tebal epidermis bawah pada bagian talus berdasarkan garis konsentris 5 dan 7 diperoleh hasil bahwa pada bagian talus ujung dengan garis konsentris 7 memiliki tebal epidermis bawah tertinggi yaitu 18,50 $\mu \mathrm{m}$ (Gambar 3.), sedangkan bagian talus tengah dengan garis konsentris 5 memiliki tebal epidermis bawah terendah yaitu $9 \mu \mathrm{m}$.

Berdasarkan hasil analisis Uji t menunjukkan terdapat perbedaan tebal epidermis bawah antara garis konsentris 5 dan 7, dapat dilihat pada tabel 1. Rerata tebal epidermis atas dan bawah tertinggi yaitu terdapat pada garis konsentris 7 masing-masing 28,33 $\mu \mathrm{m}$ dan $18 \mu \mathrm{m}$, sedangkan rerata tebal epidermis bawah terendah terdapat pada garis konsentris 5 dengan epidermis atas 20,05 $\mu \mathrm{m}$ dan epidermis bawah 12,55 $\mu \mathrm{m}$. Epidermis merupakan lapisan terluar umumnya tersusun oleh satu lapis, terdapat pada permukaan bagian atas dan bawah. Lapisan epidermis permukaan atas umumnya lebih tebal daripada epidermis permukaan bawah. Samiyarsih et al., (2017) melaporkan bahwa tebal tipisnya epidermis sangat dipengaruhi oleh kondisi lingungan akuatik tempat tumbuh. Menurut Geraldino et al (2005)., semakin banyaknya garis konsentris pada talus rumput laut, maka penebalan epidermis semakin bertambah. Epidermis merupakan jaringan paling luar yang menutupi permukaan organ tumbuhan, berfungsi sebagai pelindung jaringan yang terdapat pada bagian dalam.

Rerata tebal talus tertinggi diperoleh pada garis konsentris 7 yaitu $114,778 \mu \mathrm{m}$, sedangkan tebal talus terendah terdapat pada garis konsentris 5 yaitu 99,444 $\mu \mathrm{m}$. Setiap bagian talus memiliki variasi ketebalan yang berbeda. Hayashi et al., (2008) menyatakan bahwa kondisi lingkungan rumput laut (cahaya, suhu, $\mathrm{pH}$, salinitas) sangat menentukan kecepatan rumput laut dalam memenuhi kebutuhan nutrisi untuk pertumbuhan talus. Pertumbuhan rumput laut merupakan pertambahan ukuran sel atau perubahan dari keadaan sejumlah sel membentuk organ yang mempunyai struktur dan fungsi yang berbeda. Rumput laut $P$. australis Hauck dengan garis konsentris 5 dan 7 secara umur terihat jelas berbeda. $P$. australis Hauck yang dengan garis konsentris 5 secara morfologi memiliki tebal talus yang sangat tipis dan mudah robek dibandingkan dengan garis konsentris 7. Menurut Geraldino et al (2005)., ketebalan talus berkaitan dengan umur dari rumput laut, semakin tua umur rumput laut maka ketebalan talus rumput laut semakin bertambah. Bertambahnya garis konsentris maka diindikasikan pertumbuhan umur, volume dan berat semakin meningkat.

Rerata diameter medula tertinggi terdapat pada garis konsentris 7 yaitu $45,50 \mu \mathrm{m}$, sedangkan diameter medula terendah terdapat pada garis konsentris 5 dengan $37,88 \mu \mathrm{m}$ (Tabel 1.). Perbedaan diameter medula antara garis konsentris 5 dan 7 didasarkan perbedaan umur dari masing-masing talus rumput laut. Jaringan rumput laut memiliki bentuk bulat lonjong pada bagian luar permukaan, dan akan semakin membesar pada bagian tengah talus serta tersusun tidak beraturan. Menururt Darmawati (2012), sel korteks berukuran lebih kecil dengan bentuk memanjang, dinding sel tebal dan padat pada lapisan bagian permukaan talus. Sel korteks 
tersebut berkurang secara linier dan berkembang menjadi sel medula. Sel medula yang terdapat pada bagian tengah talus berukuran lebih besar dan bulat, namun tidak terlalu padat jika dibandingkan dengan sel korteks. Handayani (2006), mengatakan bahwa pemotongan melintang rumput laut, medula berisi sel sel bulat atau poligonal dengan bagian menebal (lenticular thickening) pada bagian dinding, dikelilingi oleh sel yang berukuran kecil.

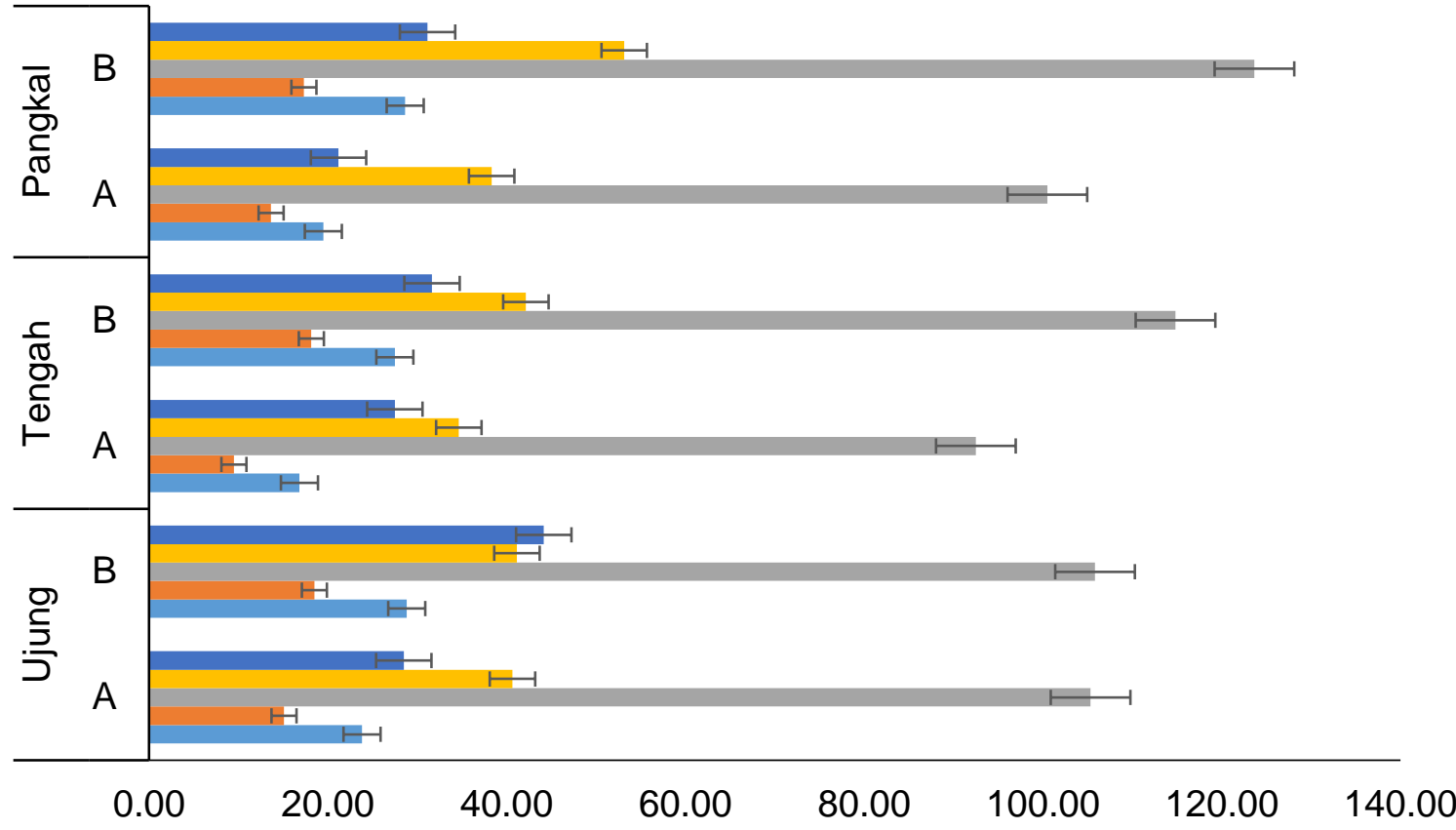

Karakter anatomi $P$. australis $(\mu \mathrm{m})$

- Tebal Tetrasporangia $(\mu \mathrm{m}) \quad$ Tebal Medula $(\mu \mathrm{m}) \quad \square$ Tebal Talus $(\mu \mathrm{m})$

$\square$ Epidermis Bawah $(\mu \mathrm{m}) \quad$ Epidermis Atas $(\mu \mathrm{m})$

Gambar 3. Variasi karakter anatomi $P$. australis berdasarkan perbedaan garis konsentris

Tabel 1. Uji t karakter anatomi $P$. australis

\begin{tabular}{lcccc}
\hline \multicolumn{1}{c}{ Parameter } & $\begin{array}{c}\text { Garis } \\
\text { Konsentris }\end{array}$ & Rerata \pm SD & t Hitung & $\begin{array}{c}\text { t Tabel } \\
, 05\end{array}$ \\
\hline Epideremis Atas & K5 & $20.056 \pm 4.209$ & $5.721^{*}$ & 2.002 \\
Epidermis Bawah & K7 & $28.333 \pm 1.061$ & & \\
& K5 & $12.556 \pm 4.202$ & $3.757^{*}$ & 2.002 \\
Tebal Talus & K7 & $18.000 \pm 1.118$ & & \\
Tebal Medula & K5 & $99.444 \pm 9.907$ & $2.982^{*}$ & 2.002 \\
Tebal Tetrasporangia & K5 & $114.778 \pm 11.825$ & & \\
& K7 & $37.889 \pm 4.519$ & $2.384^{*}$ & 2.262 \\
& K5 & $25.667 \pm 4.300$ & & \\
& K7 & $35.667 \pm 7.027$ & $3.64^{*}$ & 2.002 \\
\hline
\end{tabular}

Pengukuran rataan diameter tetrasporangia berdasarkan garis konsentris 5 dan 7 diperoleh hasil bahwa pada tetrasporangia bagian ujung dengan garis konsentris 7 memiliki diameter tetrasporangia tertinggi yaitu $44,16 \mu \mathrm{m}$, sedangkan bagian pangkal dengan garis konsentris 5 memiliki diameter tetrasporangia terendah $21 \mu \mathrm{m}$ (Gambar 3.). Berdasarkan hasil analisis Uji $\mathrm{t}$ 
menunjukkan bahwa terdapat perbedaan diameter tetrasporangia antara garis konsentris 5 dan 7 , dapat dilihat pada Tabel 1. Rerata diameter tetrasporangia tertinggi terdapat pada garis konsentris 7 yaitu 35,66 $\mu \mathrm{m}$, sedangkan diameter tetrasporangia terendah terdapat pada garis konsentris 5 dengan 25,66 $\mu \mathrm{m}$ (Tabel 1.). Tetrasporangia merupakan sistem reproduksi yang dimiliki oleh $\mathrm{P}$. australis Hauck. Adapun bentuk dan ukuran tetrasporangia pada masing-masing jenis sangat bervariasi. Perbedaan ukuran atau diameter tetrasporangia pada garis konsentris 5 dan 7 didasarkan perbedaan umur dari masing-masing talus. Menurut Kepel et al (2015)., indikasi pertumbuhan diantaranya ditunjukkan berdasarkan pertambahan berat basah dan panjang talus serta banyaknya concentric hair lines atau garis konsentris pada permukaan talus.

Kondisi lingkungan perairan dapat digambarkan melalui informasi parameter lingkungan perairan. Adapun parameter lingkungan yang diukur pada penelitian ini meliputi suhu, $\mathrm{pH}$ dan salinitas. Berikut di bawah ini merupakan nilai parameter lingkungan perairan di Pantai Karang Tengah, Pulau Nusakambangan, Cilacap, dapat dilihat pada Tabel 2.

Tabel 2. Parameter lingkungan pengambilan sampel di Pantai Karang Tengah, Cilacap

\begin{tabular}{cccc}
\hline Parameter & Pasir & Karang & Campuran \\
\hline Temperatur $\left({ }^{\circ} \mathrm{C}\right)$ & $33-34$ & $32-34.5$ & $30-34$ \\
Salinitas $\left(\mathrm{Ns} / \mathrm{m}^{2}\right)$ & $30-32$ & $31-33$ & $30-33$ \\
$\mathrm{pH}$ & $7-8$ & $7.5-8$ & $7-8$ \\
\hline
\end{tabular}

Kondisi temperatur perairan di Pantai Karang Tengah berkisar $30-34^{\circ} \mathrm{C}$. Temperatur perairan di lokasi penelitian ini sedikit lebih tinggi dari temperatur optimal pertumbuhan rumput laut yang berkisar $20-30^{\circ} \mathrm{C}$. Menurut Dawes (1998), suhu air dapat berpengaruh terhadap beberapa fungsi fisiologi, seperti fotosintesis, metabolisme, pertumbuhan, dan reproduksi rumput laut. Rumput laut mempunyai kisaran suhu yang spesifik karena adanya enzim yang tidak dapat berfungsi jika suhu terlalu dingin maupun panas.

Salinitas pada lokasi sampling di Pantai Karang Tengah, Cilacap berkisar 30-33 ppm. Menurut Trono dan Ganzon-Fortes (1988), keanekaragaman spesies lebih tinggi di perairan yang kondisi salinitasnya lebih stabil dibanding dengan perairan yang kondisi salinitasnya tidak stabil. Menurut Luning (1990), setiap rumput laut memiliki toleransi terhadap kisaran salinitas tertentu untuk dapat hidup dan bertumbuh secara maksimum. Menurut Chapman dan Chapman (1980), salinitas yang tinggi maupun rendah akan menyebabkan perubahan pada tekanan osmosis sel tubuh dengan lingkungannya. Menurut Kadi \& Atmadja (1988), kisaran salinitas yang baik untuk pertumbuhan rumput laut yaitu 30-34 ppm. Menurut Sulistijo (1989), salinitas yang rendah di bawah $30 \mathrm{ppm}$, kurang baik untuk pertumbuhan rumput laut karena rumput laut tersebut akan terserang penyakit ice-ice dan mengakibatkan kematian. Hasil pengukuran salinitas di Pantai Karang Tengah termasuk kategori baik untuk pertumbuhan rumput laut cokelat $P$. australis Hauck.

Nilai derajat keasaman $(\mathrm{pH})$ yang diperoleh di Pantai Karang Tengah, Cilacap yaitu 7-8. Menurut Aslan (1998), hampir seluruh rumput laut mempunyai adaptasi terhadap kisaran $\mathrm{pH}$ yaitu 6,8-9,6. Derajat keasaman atau $\mathrm{pH}$ digambarkan sebagai keberadaan ion hidrogen. Nilai $\mathrm{pH}$ berpengaruh terhadap kelarutan dan ketersediaan ion mineral sehingga mempengaruhi penyerapan nutrien oleh sel. Hasil pengukuran $\mathrm{pH}$ di Pantai Karang Tengah, Cilacap menunujukkan kisaran $\mathrm{pH}$ yang normal pada perairan laut serta baik untuk pertumbuhan rumput laut cokelat P. australis Hauck. Selain itu, hasil pengukuran $\mathrm{pH}$ perairan ini tergolong baik dan sesuai dengan standar baku kualitas air laut berdasarkan Direktorat Jenderal Perikanan (1982), yaitu antara 6,5-8.

\section{KESIMPULAN}

Variasi karakter anatomi talus Padina australis Hauck berdasarkan garis konsentris 5 maupun 7 memiliki ukuran yang berbeda pada tebal epidermis atas, tebal epidermis bawah, tebal talus, diameter medula dan diameter tetrasporangia. Implikasi penelitan adalah sebagai database pada data dasar pengelolaan $P$. australis antara varaisi anatomi-taksonomidan produksi alginat. 


\section{DAFTAR PUSTAKA}

Abbas, A., \& Shameel, M. 2013. Morpho-anatomical studies on the genus Padina (Dictyotales, Phaeophycota) from the Coast of Karachi, Pakistan. Proceeding Pakistan Academic Science, 50:21-36

Aslan, L.M. 1998. Budidaya Rumput Laut. Penerbit Kanisius. Yogyakarta.

Chapman, V.J. \& Chapman, D.J., 1980. Seaweed and their Uses. with chapterd by D.J. Chapman, Chapman and Hill. London.

Darmawati. 2012. Perubahan Sel Rumput Laut Kappaphycus alvarezii Yang Dibudidayakan Pada Kedalaman Berbeda. Octopus. 1(2):65-69.

Dawes J.C. 1998. Marine Botany. Second Edition A Wiley Interscience Publication. The United States of America.

Direktorat Jendral Perikanan, 1982. Petunjuk teknis budidaya laut. Dit-Jen Perikanan. Jakarta : 24 hal.

Gerasimenko, N.I., Busarova, N.G., \& Moiseenko, O.P. 2010. Seasonal Changes in the Content of Lipids, Fatty Acids, and Pigments in Brown Alga Costaria costata. Russian Journal Plant Physiology. 57 (2):205-211. DOI: 10.1134/S102144371002007X

Hayashi, L., Yokoya, N.S., Ostini, S., Pereira, R.T.L., Braga, E.S., \& Olivera, E.C. 2008. Nutrients Removed by Kappaphycus alvarezii in Integrated Cultivation with Fishes in Re-Circulating Water. Aquaculture. 277:185-191. DOI: /10.1016/j.aquaculture.2008.02.024

Kadi, A. 2005. Beberapa catatan kehadiran marga Sargassum di perairan Indonesia. Oseana, 30(4):19-29.

Kadi, A. \& Atmadja, W.S. 1988. Rumput Laut (Algae) Jenis, Reproduksi, Produksi, Budidaya dan Pasca Panen Proyek Studi Dan Potensi Sumberdaya Alam Indonesia. Pusat Pengembangan dan Penelitian Oseanografi, LIPI. Jakarta.

Mushollaeni, W., \& Rusdiana, E. 2011. Karakterisasi Natrium alginat dari Sargassum sp., Turbinaria sp., dan Padina sp. Jurnal Teknologi dan Industri Pangan, 22(1):26-32.

Pramesti, R., Susanto, A.B., Wilis, A.S., Ridlo, A., Subagiyo., \& Yohanes, O. 2016. Struktur Komunitas dan Anatomi Rumput Laut di Perairan Teluk Awur, Jepara dan Pantai Krakal, Yogyakarta. Jurnal Kelautan Tropis, 19(2):81- 64. DOI: 10.14710/jkt.v19i2.822

Qasim, A.W., Roedhy, P., Wattimena, G.A. \& Witjaksono. 2007. Perubahan Anatomi Daun Pada Regeneran Manggis Akibat Iradiasi Sinar Gamma In Vitro. Zuriat. 18(1):20-30. DOI: 10.24198/zuriat.v18i1.6745

Riosmena-Rodríguez, R.; Woelkerling, W.J. \& Foster, M.S. 1999. Taxonomic reassessment of rhodolith-forming species of Lithophyllum (Corallinales, Rhodophyta) in the gulf of California, Mexico. Phycologia. 38:401-417. DOI: 10.2216/i0031-8884-38-5-401.1

Samiyarsih, S., Azizah, E. \& Herawati, W. 2020. Anatomical profile and genetic variability of sweet potato (Ipomoea batatas) cultivars in Banyumas, Central Java, based on RAPD markers. Biodiversitas, 21(4):1755-1766. DOI: 10.13057/biodiv/d210460

Sulistijo. 1989. Budidaya Rumput Laut. Upaya Pengembangan Rumput Laut Eucheuma dan Gracilaria. Makalah Diajukan Pada Workshop Budidaya Rumput Laut di Bandar Lampung. Bandar Lampung.

Trono, G.C. \& Ganzon Fortez, E. 1988. Philippine Seaweeds. Nation Book Store Inc. Publisher Metro Manila. Philippines.

Yulianto, B., Ario, R., \& Agung, T. 2006. Daya Serap Rumput Laut (Gracilaria sp) Terhadap Logam Berat Tembaga (Cu) Sebagai Biofilter. IImu Kelautan: Indonesian Journal of Marine Sciences, 11(2):72-78. DOI: 10.14710/ik.ijms.11.2.72-78. 